\title{
Faktor-faktor yang Berperan terhadap Terjadinya Kecemasan Orang Tua Anak Sekolah Dasar di Desa Maumbi pada Masa Pandemi Covid -19
}

\author{
Kristinia M. Tangkuman, ${ }^{1}$ Anita E. Dundu, ${ }^{2}$ Theresia M. D. Kaunang ${ }^{2}$
}

\author{
${ }^{1}$ Program Studi Pendidikan Dokter Fakultas Kedokteran Universitas Sam Ratulangi, Manado, \\ Indonesia \\ ${ }^{2}$ Bagian Ilmu Kedokteran Jiwa Fakultas Kedokteran Universitas Sam Ratulangi, Manado, \\ Indonesia \\ E-mail: kristiniatangkuman@gmail.com
}

\begin{abstract}
The 2019 Coronavirus Disease (COVID-19) pandemic has changed the learning pattern to distance learning, which is an online system. Besides their other activities, parents play a more important role in accompaning and guiding their children during online learning than that of the teachers. Therefore, the parents endure uncomfortable feelings such as anxiety due to increased burden. Moreover, there are various factors that can play a role in the occurrence of parental anxiety. During this pandemic, online learning has also penetrated into the countryside. Maumbi village is one of the areas affected by the COVID-19 pandemic. This study was aimed to analyze the factors that contribute to the anxiety of parents of elementary school children at Maumbi village during the COVID-19 pandemic. This was a descriptive and analytical study with a cross sectional design. Data of this study were obtained by using the Hamilton Anxiety Rating Scale (HARS) questionnaire. Samples of this study were 107 parents of elementary school children who met the inclusion and exclusion criteria. The multivariate analysis showed that the factors that contributed to the anxiety level of parents were economic stressors $(\mathrm{p}=0.021, \mathrm{t}$ count $=-2.347$, and $\beta=-0.224$ ) and occupational stressors ( $p=0.042$, $t$ count $=-2.055$, and $\beta=-0.197)$. In conclusion, factors contributing to the anxiety of parents of elementary school children at Maumbi village during the COVID-19 pandemic were economic stressors and occupational stressors.
\end{abstract}

Keywords: parents' anxiety; level of anxiety; online learning; COVID-19 pandemic

\begin{abstract}
Abstrak: Pandemi coronavirus disease 2019 (COVID-19) membuat pola pembelajaran berubah menjadi pembelajaran jarak jauh. Disamping kesibukan lainnya, orang tua berperan untuk mendampingi dan membimbing anak ketika berlajar online yang jauh lebih besar daripada guru. Orang tua merasa tidak nyaman seperti kecemasan akibat beban yang bertambah. Berbagai macam faktor dapat berperan terhadap terjadinya kecemasan orang tua anak. Dalam masa pandemi ini untuk pembelajaran daring atau online juga sudah merambah sampai ke pedesaan. Desa Maumbi merupakan salah satu daerah yang tekena dampak pandemi COVID-19. Penelitian ini bertujuan untuk menganalisis faktor-faktor yang berperan terhadap terjadinya kecemasan orang tua anak sekolah dasar di Desa Maumbi pada masa pandemi COVID-19. Jenis penelitian ialah deskriptif analitik dengan desain potong lintang. Pengumpulan data penelitian diambil dengan kuesioner Hamilton Anxiety Rating Scale (HARS). Sampel penelitian ini ialah 107 orang tua anak sekolah dasar yang memenuhi kriteria inklusi dan eksklusi. Hasil analisis multivariat menunjukkan bahwa faktor-faktor yang berperan terhadap terjadinya tingkat kecemasan orang tua anak SD di Desa Maumbi pada masa pandemi COVID-19 ialah stresor ekonomi $(\mathrm{p}=0,021$, $\mathrm{t}$ hitung $=-2.347$, dan $\beta=-0,224)$ dan stresor pekerjaan ( $p=0,042$, t hitung $=-2,055$, dan $\beta=-0,197$ ). Simpulan penelitian ini ialah faktor-faktor yang berperan terhadap terjadinya kecemasan orang tua anak sekolah dasar di Desa Maumbi pada masa pandemi COVID-19 ialah stresor ekonomi dan stresor pekerjaan.

Kata kunci: kecemasan orang tua; tingkat kecemasan; pembelajaran jarak jauh; pandemi COVID-19
\end{abstract}




\section{PENDAHULUAN}

Coronavirus disease 19 (COVID-19) adalah penyakit infeksi saluran pernapasan yang disebabkan oleh severe acute respiretory syndrom coronavirus 2 (SARS-CoV2). ${ }^{1}$ Pada awal Desember 2019, kasus pneumonia pertama yang tidak diketahui penyebabnya teridentifikasi di Wuhan, ibu kota provinsi Hubei. ${ }^{2}$ Penyebab kasus tersebut berbeda dari MERS-CoV dan SARS-CoV, ${ }^{3}$ dan teridentifikasi sebagai jenis baru coronavirus yang saat ini dinamai severe acute respiratory syndrom coronavirus 2 (SARSCoV-2). ${ }^{4}$ Pada tanggal 30 Januari 2020 World Health Organization (WHO) menetapkan kejadian tersebut sebagai Public Health Emergency of International Concern (PHEIC) dan kemudian menetapkannya sebagai pandemi pada 11 Maret $2020 .^{5}$

Total kasus dunia hingga tanggal 22 Oktober 2020 kurang lebih 51,848,261 kasus yang dikonfirmasi, termasuk 1,280,868 kematian yang dilaporkan ke WHO. ${ }^{6} \mathrm{Di}$ Indonesia, data terkini dari Satuan Tugas Penanganan Covid-19 tentang jumlah kasus positif Covid-19 masih menunjukkan peningkatan yaitu sebanyak 452,291 kasus. Tingkat kematian pasien Covid-19 14,933 orang $(4,0 \%)$ dan 382.084 orang dinyatakan sembuh dari jumlah penderita positif. Di Sulawesi Utara dilaporkan jumlah kasus Covid-19 sebanyak 5.827 kasus $(2,1 \%){ }^{7}$

Kasus terkonfirmasi Covid-19 terus bertambah di belahan dunia termasuk Indonesia. Pemerintah Indonesia menetapkan Keputusan Presiden Nomor 11 Tahun 2020 tentang Penetapan Kedaruratan Kesehatan Masyarakat COVID-19 sebagai jenis penyakit yang menimbulkan Kedaruratan Kesehatan Masyarakat (KKM). Penanggulangan KKM dilakukan melalui penyelenggaraan kekarantinaan kesehatan yang pada prinsipnya untuk menekan penyebaran COVID-19 yang semakin meluas sehingga semua kegiatan yang dilakukan di luar rumah harus dihentikan dan dilakukan dari rumah. ${ }^{1}$

Tindakan kesehatan masyarakat, seperti tindakan isolasi sosial atau karantina, sangat penting untuk perlindungan individu dan untuk mengurangi risiko kemungkinan kontak dengan COVID-19. Namun pada saat yang sama, masyarakat mengalami beban kondisi kesehatan mental yang tinggi. Suasana hati tertekan, mudah marah, kecemasan, tingkat stres tinggi, dan insomnia merupakan beberapa contoh umum dari hasil kesehatan mental tertentu yang terkait dengan isolasi. ${ }^{8}$

Keputusan pemerintah menerapkan kebijakan karantina membuat pola pembelajaran juga berubah menjadi pembelajaran jarak jauh yaitu sistem dalam jaringan (daring) atau online. Keterbatasan pengetahuan akan teknologi menjadi salah satu kendala dalam sistem pembelajaran daring ini. Terutama orang tua pada situasi ini dituntut untuk membimbing anak-anaknya dalam pembelajaran berbasis online.

Orang tua mempunyai peran penting dalam menangani situasi ini. Orang tua dapat menjadi jembatan antara sekolah dan siswa, khususnya untuk tingkat sekolah dasar karena anak-anak tidak memiliki alat komunikasi yang dimiliki sendiri, seperti ponsel atau perangkat computer. Selain itu, oleh karena pemahaman yang kurang dalam melakukan pembelajaran online maka orang tua harus menjadi mediator bagi anak dan sekolah. ${ }^{9}$

Peranan orang tua untuk mendampingi dan membimbing anak ketika berlajar online jauh lebih besar dari pada guru. Sementara itu orang tua punya kesibukan lainnya seperti harus bekerja untuk mencari nafkah, bersih-bersih rumah, dan kegiatan lainnya. Orang tua merasakan perasaan tidak nyaman seperti kecemasan, kemarahan, dan kesedihan akibat beban yang bertambah semenjak karantina.

Kecemasan merupakan emosi universal, ${ }^{10}$ dan sering kali merupakan reaksi yang normal dan berperan terhadap situasi stres. ${ }^{11}$ Kecemasan sering dialami oleh hampir semua manusia. Perasaan tersebut ditandai oleh rasa ketakutan yang difus, tidak menyenangkan, dan samar-samar, seringkali disertai oleh gejala otonomik, seperti nyeri kepala, berkeringat, palpitasi, kekakuan pada dada, dan gangguan lambung ringan. Seseorang yang cemas mungkin juga merasa gelisah, seperti ketidakmampuan untuk duduk atau berdiri lama. ${ }^{12}$ 
Gangguan kecemasan merupakan masalah kesehatan mental yang paling umum di Amerika Serikat yang memengaruhi $18,1 \%$ orang dewasa dalam populasi umum pada tahun tertentu, dan $28,8 \%$ orang dewasa di beberapa titik selama hidup mereka. ${ }^{11}$

Cameron et $\mathrm{al}^{13}$ mengevaluasi prevalensi depresi dan kecemasan pada ibu dengan anak berusia 0-8 tahun selama pandemi COVID-19. Hasil identifikasinya mendapatkan bahwa terjadi peningkatan kecemasan dari 29,59\% meningkat menjadi $36,27 \%$. Kecemasan orang tua yang mengurus anak usia 5-8 tahun yang duduk di bangku kelas 1 dan 2 berhubungan dengan riwayat kesehatan mental, kehilangan pekerjaan, dan ketegangan keuangan.

Dalam masa pandemi ini untuk pembelajaran daring atau online juga sudah merambah sampai ke pedesaan. Desa Maumbi merupakan salah satu daerah yang tekena dampak dari pandemi COVID-19. Sekolahsekolah di Desa Maumbi juga menerapkan sistem pembelajaran daring atau online. Berdasarkan latar belakang ini maka penulis tertarik untuk melakukan penelitian terhadap orang tua anak sekolah dasar pada masa pandemi yaitu mengenai faktor-faktor yang berperan terhadap terjadinya kecemasan orang tua anak sekolah dasar di Desa Maumbi pada masa pandemi COVID-19.

\section{METODE PENELITIAN}

Penelitian ini dilaksanakan di tiga sekolah dasar di Desa Maumbi pada bulan November-Desember 2020. Jenis penelitian ini ialah deskriptif analitik dengan desain potong lintang. Data penelitian ini diperoleh dengan menggunakan kuesioner Hamilton Anxiety Rating Scale (HARS). Populasi penelitian ialah orang tua anak sekolah dasar (SD). Populasi target dalam penelitian ini ialah orang tua anak sekolah dasar di Desa Maumbi. Rerponden dalam penelitian ini ialah 107 orang tua anak sekolah dasar di Desa Maumbi yang memenuhi kriteria inklusi dan eksklusi.

Kriteria inklusi pengambilan sampel yaitu 1) Orang tua anak kelas 1-2 SD; 2) Orang tua yang membimbing anaknya ketika sekolah daring; dan 3) Bersedia menjadi responden dan mengisi kuesioner.

Pengumpulan data pada penelitian ini dikumpulkan dari reponden melalui kuesioner HRS-A, data demografi, dan angket dengan variabel yang diukur ialah usia, tingkat pendidikan, jenis pekerjaan, status ekonomi, riwayat kecemasan keluarga, stresor ekonomi, stresor pekerjaan, waktu untuk mendampingi anak, penggunaan perangkat gadget/elektronik, menguasai dan memahami penggunaan gadget/elektronik, dan kebiasaan mendampingi anak. Sebelumnya peneliti membuat informed concent bahwa responden bersedia ikut serta dalam penelitian dan dimintakan untuk mengisi kuesioner yang berisi daftar pertanyaan tertulis.

Analisis data penelitian ini yaitu analisis univariat untuk deskripsi data seperti frekuensi dan persentase dari tiap variabel, dilanjutkan dengan analisis bivariat untuk menjelaskan dua hubungan yang bermakna antara variabel dependen dan independen menggunakan analisis data uji chi square, dan analisis multivariat menggunakan analisis data regresi logistik berganda.

\section{HASIL PENELITIAN}

Pada penelitian ini didapatkan 107 responden yang memenuhi kriteria inklusi dan eksklusi. Tabel 1 memperlihatkan hasil analisis univariat terhadap tingkat kecemasan pada responden berdasarkan usia, tingkat pendidikan, jenis pekerjaan, status ekonomi, riwayat kecemasan keluarga, stresor ekonomi, stresor pekerjaan, waktu untuk mendampingi anak, penggunaan perangkat gadget/elektronik, menguasai dan memahami penggunaan gadget/elektronik, dan kebiasaan mendampingi anak.

Analisis bivariat digunakan untuk melihat kekuatan hubungan antara dua variabel yaitu masing-masing usia, tingkat pendidikan, pekerjaan, status ekonomi, status pernikahan, status orang tua, genetik, stresor ekonomi, stresor pekerjaan, waktu mendampingi, penggunaan perangkat, pemahaman penggunaan perangkat, dan kebiasaan mendampingi terhadap tingkat kecemasan dengan menggunakan uji chi square.

Tabel 2 memperlihatkan terdapatnya 
hubungan bermakna antara stresor ekonomi, stresor pekerjaan, dan kebiasaan mendampingi anak dengan tingkat kecemasan orang tua. Dikatakan terdapat hubungan bermakna karena nilai $\mathrm{x}^{2}$ hitung $>\mathrm{x}^{2}$ tabel dan $\mathrm{p}<0,05$.

Tabel 1. Analisis univariat dari variabel penelitian

\begin{tabular}{|c|c|c|c|c|c|c|c|c|c|c|c|}
\hline \multirow[b]{2}{*}{ Variabel } & \multirow[b]{2}{*}{ Kategori } & \multicolumn{8}{|c|}{ Tingkat Kecemasan } & \multirow[b]{2}{*}{ Frekuensi } & \multirow[b]{2}{*}{$\%$} \\
\hline & & $\mathrm{T}$ & $\%$ & $\mathrm{R}$ & $\%$ & $\mathrm{~S}$ & $\%$ & B & $\%$ & & \\
\hline \multirow{4}{*}{ Usia (tahun) } & $17-25$ & 2 & 50 & 1 & 25 & 1 & 25 & 0 & 0.0 & 4 & 3,7 \\
\hline & $26-35$ & 20 & 37 & 8 & 14,8 & 8 & 14,8 & 18 & 33,3 & 54 & 50,5 \\
\hline & $36-45$ & 10 & 23,8 & 3 & 7,1 & 14 & 33,3 & 15 & 35,7 & 42 & 39,3 \\
\hline & $46-55$ & 3 & 42,9 & 0 & 0,0 & 1 & 14,3 & 3 & 42,9 & 7 & 6,5 \\
\hline \multirow{4}{*}{ Pendidikan } & SD & 5 & 45,5 & 3 & 27,3 & 2 & 18,2 & 1 & 9,1 & 11 & 10,3 \\
\hline & SMP & 3 & 15,8 & 2 & 10,5 & 5 & 26,3 & 9 & 47,4 & 19 & 17,8 \\
\hline & SMA/SMK & 15 & 32,6 & 6 & 13 & 10 & 21,7 & 15 & 32,6 & 46 & 43,0 \\
\hline & $\begin{array}{l}\text { Perguruan tinggi } \\
\text { atau sederajat }\end{array}$ & 12 & 38,7 & 1 & 3,2 & 7 & 22,6 & 11 & 35,5 & 31 & 29,0 \\
\hline \multirow{7}{*}{ Pekerjaan } & IRT & 17 & 29,3 & 9 & 15,5 & 10 & 19 & 20 & 36,2 & 56 & 52,3 \\
\hline & Pegawai swasta & 7 & 25,9 & 2 & 7,4 & 10 & 37 & 8 & 29,6 & 26 & 24,3 \\
\hline & Wiraswasta & 7 & 63,6 & 0 & 0,0 & 3 & 27,3 & 2 & 9,1 & 13 & 12,2 \\
\hline & PNS & 3 & 42,9 & 0 & 0,0 & 0 & 0,0 & 4 & 57,1 & 8 & 7,5 \\
\hline & Perangkat Desa & 1 & 100 & 0 & 0,0 & 0 & 0,0 & 0 & 0,0 & 1 & 0,9 \\
\hline & Honorer & 0 & 0,0 & 0 & 0,0 & 0 & 0,0 & 1 & 100 & 1 & 0,9 \\
\hline & THL & 0 & 0,0 & 1 & 50 & 0 & 0,0 & 1 & 50 & 2 & 1,9 \\
\hline \multirow{3}{*}{ Status ekonomi } & Ekonomi bawah & 10 & 32,3 & 5 & 16,1 & 7 & 22,6 & 9 & 29 & 31 & 29,0 \\
\hline & $\begin{array}{l}\text { Ekonomi } \\
\text { menengah }\end{array}$ & 3 & 15,8 & 4 & 21,1 & 3 & 15,8 & 7 & 47,4 & 19 & 17,8 \\
\hline & Ekonomi atas & 22 & 38,6 & 3 & 5,3 & 14 & 24,6 & 18 & 31,6 & 57 & 53,3 \\
\hline \multirow{2}{*}{$\begin{array}{l}\text { Riwayat kece- } \\
\text { masan keluarga }\end{array}$} & $\mathrm{Ya}$ & 9 & 37,5 & 1 & 4,2 & 6 & 25 & 8 & 33,3 & 24 & 22,4 \\
\hline & Tidak & 26 & 31,3 & 11 & 13,3 & 18 & 16,8 & 28 & 33,6 & 83 & 77,6 \\
\hline \multirow{2}{*}{ Stresor ekonomi } & Ya & 18 & 26,1 & 9 & 13 & 13 & 18,8 & 29 & 42 & 69 & 64,5 \\
\hline & Tidak & 17 & 44,7 & 3 & 7,9 & 11 & 28,9 & 7 & 18,4 & 38 & 35,5 \\
\hline \multirow{2}{*}{ Stresor pekerjaan } & Ya & 16 & 25,4 & 5 & 7,9 & 19 & 30,2 & 23 & 29,5 & 63 & 58,9 \\
\hline & Tidak & 19 & 43,2 & 7 & 15,9 & 5 & 11,4 & 13 & 36,5 & 44 & 41,1 \\
\hline \multirow{2}{*}{ Waktu orang tua } & Ya & 28 & 30,8 & 11 & 12,1 & 21 & 23,1 & 31 & 34,1 & 91 & 85,0 \\
\hline & Tidak & 7 & 43,8 & 1 & 6,3 & 3 & 18,8 & 5 & 31,3 & 16 & 15,0 \\
\hline \multirow{2}{*}{$\begin{array}{l}\text { Penggunaan pe- } \\
\text { rangkat gadged/ } \\
\text { elektronik }\end{array}$} & Ya & 29 & 32,2 & 12 & 13,3 & 19 & 21,1 & 30 & 33,3 & 90 & 84,1 \\
\hline & Tidak & 6 & 35,3 & 0 & 0,0 & 5 & 29,4 & 6 & 35,3 & 17 & 15,9 \\
\hline \multirow{2}{*}{$\begin{array}{l}\text { Pemahaman } \\
\text { penggunaan } \\
\text { perangkat } \\
\text { gadgedl } \\
\text { elektronik }\end{array}$} & $\mathrm{Ya}$ & 35 & 34,7 & 11 & 10,9 & 22 & 21,8 & 33 & 32,7 & 101 & 94,4 \\
\hline & Tidak & 0 & 0,0 & 1 & 16,7 & 2 & 33,3 & 3 & 50 & 6 & 5,6 \\
\hline \multirow{3}{*}{$\begin{array}{l}\text { Kebiasaan } \\
\text { mendampingi } \\
\text { anak }\end{array}$} & $\begin{array}{l}\text { Biasa mendam- } \\
\text { pingi anak sejak } \\
\text { sebelum } \\
\text { Pandemi }\end{array}$ & 30 & 35,7 & 11 & 13,1 & 14 & 16,7 & 29 & 34,5 & 84 & 78,5 \\
\hline & $\begin{array}{l}\text { COVID-19 } \\
\text { Tidak mendam- } \\
\text { pingi anak sejak }\end{array}$ & & & & & & & & & & \\
\hline & $\begin{array}{l}\text { sebelum } \\
\text { Pandemi } \\
\text { COVID-19 }\end{array}$ & 5 & 21,7 & 1 & 4,3 & 10 & 43,5 & 7 & 30,4 & 23 & 21,5 \\
\hline
\end{tabular}


Tabel 2. Analisis bivariat terhadap kekuatan hubungan antara variabel penelitian

\begin{tabular}{lccccc}
\hline \multicolumn{1}{c}{ Variabel } & $\mathbf{X}^{\mathbf{2}} \mathbf{h i t u n g}$ & $\mathbf{X}^{\mathbf{2}}$ tabel & $\mathbf{P}$ & $\mathbf{d k}$ & Keterangan \\
\hline Usia & 10,038 & 16,919 & 0,347 & 9 & Tidak bermakna \\
Pendidikan & 10,296 & 16,919 & 0,327 & 9 & Tidak bermakna \\
Pekerjaan & 22,892 & 28,869 & 0,195 & 18 & Tidak bermakna \\
Status ekonomi & 8,198 & 12,591 & 0,224 & 6 & Tidak bermakna \\
Genetik & 1,680 & 7,814 & 0,641 & 3 & Tidak bermakna \\
Stresor ekonomi & 8,360 & 7,814 & 0,039 & 3 & Bermakna \\
Stresor pekerjaan & 8,427 & 7,814 & 0,038 & 3 & Bermakna \\
Waktu mendampingi & 1,260 & 7,814 & 0,739 & 3 & Tidak bermakna \\
Penggunaan perangkat & 2,764 & 7,814 & 0,430 & 3 & Tidak bermakna \\
Pemahaman penggunaan perangkat & 3,090 & 7,814 & 0,378 & 3 & Tidak bermakna \\
Kebiasaan mendampingi & 8,187 & 7,814 & 0,042 & 3 & Bermakna \\
\hline
\end{tabular}

Tabel 3. Analisis multivariat terhadap stresor ekonomi, stresor pekerjaan, dan kebiasaan mendampingi

\begin{tabular}{cccccc}
\hline Variabel & Koefisien & t hitung & $\mathbf{P}$ & $\begin{array}{c}\text { Koefisien regresi } \\
\text { (Beta) }\end{array}$ & Keterangan \\
\hline Stresor ekonomi & $-0,586$ & $-2,347$ & 0,021 & $-0,224$ & Bermakna \\
Stresor pekerjaan & $-0,502$ & $-2,055$ & 0,042 & $-0,197$ & Bermakna \\
Kebiasaan mendampingi & 0,386 & 1,324 & 0,188 & 0,126 & Tidak bermakna \\
\hline
\end{tabular}

$\mathrm{t}$ tabel $=1,98350$

Pada analisis multivariat, variabel yang menjadi kandidat model multivariat ialah variabel indepeden dengan nilai $\mathrm{p}<0,05$ dalam analisis bivariat, yaitu stresor ekonomi, stresor pekerjaan, dan kebiasaan mendampingi. Tiga variabel tersebut kemudian dianalisis dengan menggunakan analisis regresi logistik ganda. Tabel 3 memperlihatkan bahwa terdapat pengaruh bermakna antara stresor ekonomi dan stresor pekerjaan terhadap tingakt kecemasan orang tua. Dikatakan terdapat hubungan bermakna karena nilai $t$ hitung $>t$ tabel dan $p<0,05$. Variabel stresor ekonomi mempunyai koefisiensi beta yang paling besar sehingga dapat disimpulkan bahwa variabel yang paling berpengaruh terhadap tingkat kecemasan orang tua ialah stresor ekonomi.

\section{BAHASAN}

Hasil penelitian mendapatkan bahwa responden didominasi oleh usia 26-35 tahun yaitu sebanyak 54 orang $(50,55)$; di antaranya sebanyak 20 orang $(37 \%)$ tidak mengalami kecemasan. Dari semua kelompok usia, responden yang paling banyak mengalami kecemasan berat berusia 26-35 tahun sebanyak 18 orang (16,3\%). Hasil ini sejalan dengan penelitian yang dilakukan oleh Megasari et $\mathrm{al}^{14}$ yang menyatakan responden yang mengalami kecemasan berat didominasi oleh yang berada dalam kelompok usia 20-29 tahun dan jenis kelamin perempuan. Hasil uji chi square menunjukkan bahwa nilai kategori umur $\mathrm{x}^{2}$ hitung $=10,038$ dengan $p=0,347$. Nilai $x^{2}$ tabel$=16,919$ pada derajat kebebasan $(\mathrm{dk})=9$. Dengan demikian dapat diiterpretasikan bahwa tidak terdapat hubungan antara usia dengan tingkat kecemasan orang tua anak SD pada masa pandemi COVID-19.

Hasil penelitian ini mendapatkan bahwa responden yang paling banyak mengalami kecemasan memiliki tingkat pendidikan terakhir Sekolah Menengah Atas atau Sekolah Menengah Kejuruan (SMA/SMK) yaitu sebanyak 46 responden $(44,9 \%)$ dengaan tingkat kecemasan berat 15 orang $(32,6 \%)$. Hasil uji chi square menunjukkan bahwa nilai pendidikan $\mathrm{x}^{2}$ hitung $=10,296$ dengan $\mathrm{p}=0,327$. Nilai $\mathrm{x}^{2}$ tabel $=16,919$ pada derajat $(\mathrm{dk})=9$. Dengan demikian dapat diinterpre- 
tasikan bahwa tidak terdapat hubungan antara pendidikan dengan tingkat kecemasan karena nilai $\mathrm{x}^{2}$ hitung $<\mathrm{x}^{2}$ tabel.

Pada penelitian ini didapatkan bahwa responden yang paling banyak mengalami kecemasan memiliki pekerjaan sebagai ibu rumah tangga (IRT) yaitu sebanyak 56 responden $(53,1 \%)$ dengaan tingkat kecemasan berat 20 orang $(36,2 \%)$. Hasil ini tidak sejalan dengan penelitian oleh Megasari et $\mathrm{al}^{14}$ yang menyatakan bahwa yang mengalami kecemasan berat ialah mereka yang bekerja di sektor swasta. Hasil uji chi square menunjukkan bahwa nilai pekerjaan $\mathrm{x}^{2}$ hitung $=22,892$ dengan $\mathrm{p}=0,195$. Nilai $\mathrm{x}^{2}$ tabel $=28,869$ pada derajat $(\mathrm{dk})=18$. Dengan demikian dapat diinterpretasikan bahwa tidak terdapat hubungan antara pekerjaan dengan tingkat kecemasan karena nilai $\mathrm{x}^{2}$ hitung $<\mathrm{x}^{2}$ tabel.

Hasil penelitian ini memperlihatkan bahwa responden didominasi oleh yang memiliki status ekonomi dengan pendapatan/bulan $\geq$ Rp 2.000.000 yaitu sebanyak 57 responden $(53,1 \%)$ terdiri dari 22 orang $(38,6 \%)$ yang tidak mengalami kecemasan, 18 orang $(31,6 \%)$ mengalami kecemasan berat, 14 orang $(24,6 \%)$ mengalami kecemasan sedang, dan tiga orang $(5,3 \%)$ mengalami kecemasan ringan. Hasil uji chi square menunjukkan bahwa nilai status ekonomi $\mathrm{x}^{2}$ hitung $=8,198$ dengan $\mathrm{p}=0,224$. Nilai $\mathrm{x}^{2}$ tabel $=12,591$ pada derajat $(\mathrm{dk})=6$ sehingga dapat diinterpretasikan bahwa tidak terdapat hubungan antara status ekonomi dengan tingkat kecemasan orang tua karena nilai $\mathrm{x}^{2}$ hitung $<\mathrm{x}^{2}$ tabel.

Hasil penelitian ini memperlihatkan bahwa pada 107 reponden didapatkan orang tua yang tidak memiliki riwayat gangguan kecemasan dalam keluarga sebanyak 83 responden $(77,1 \%)$ dengan tingkat kecemasan berat 28 orang $(33,6 \%)$, tidak mengalami kecemasan 26 orang $(31,3 \%)$, kecemasan sedang 18 orang $(16,8 \%)$, dan kecemasan ringan 11 orang $(13,3 \%)$. Hasil uji chi square menunjukkan bahwa nilai genetik $\mathrm{x}^{2}$ hitung $=1,680$ dengan $\mathrm{p}=0,680$. Nilai $\mathrm{x}^{2}$ tabel $=7,814$ pada derajat $(\mathrm{dk})=3$ sehingga dapat diinterpretasikan bahwa tidak terdapat hubungan antara riwayat gangguan kecemasan dalam keluarga dengan tingkat kecemasan orang tua karena nilai $x^{2}$ hitung $<x^{2}$ tabel.

Pada penelitian ini didapatkan bahwa orang tua yang memiliki stresor ekonomi atau masalah ekonomi ialah sebanyak 69 responden $(64,1 \%)$ dengan tingkat kecemasan berat 29 orang $(42 \% \%)$, kecemasan sedang 13 orang $(18,8 \%)$, dan kecemasan ringan 9 orang (13\%). Hasil penelitian ini sejalan dengan penelitian oleh Ayu et $\mathrm{al}^{15}$ yang menyatakan $51,8 \%$ merasa cemas dalam konteks ekonomi dimana orang tua diharuskan mengeluarkan biaya lebih untuk memenuhi kebutuhan pendidikan anak yang dilakukan secara daring. Selain itu juga diakibatkan oleh krisis ekonomi terkait dengan penutupan bisnis dan diberhentikan dari tempat kerja karena pandemi Covid-19. Hasil uji chi square menunjukkan bahwa nilai stresor ekonomi $\mathrm{x}^{2}$ hitung $=8,360$ dengan $\mathrm{p}=0,039$. Nilai $\mathrm{x}^{2}$ tabel $=7,814$ pada derajat $(\mathrm{dk})=3$ sehingga dapat diinterpretasikan bahwa terdapat hubungan bermakna antara stresor ekonomi dengan tingkat kecemasan orang tua karena nilai $\mathrm{x}^{2}$ hitung $>x^{2}$ tabel dan $p<0,05$. Pada hasil analisis regresi linear berganda, stresor ekonomi memiliki nilai t hitung sebesar 2,347 dengan $p=0,021$. Nilai ini lebih besar dari pada t tabel yaitu 1,983 dan $p>0,05$. Hal ini menjelaskan bahwa masalah ekonomi berperan tingkat kecemasan orang tua di masa pandemi COVID-19.

Berdasarkan hasil penelitian, stresor ekonomi menjadi faktor yang paling berperan terhadap tingkat kecemasan orang tua dimana didapatkan bahwa 69 (64,5\%) responden memiliki masalah ekonomi. Hal ini dipengaruhi karena selama masa pandemi pendapatan orang tua menurun atau berkurang dari sebelumnya. Selain itu pengeluaran menjadi lebih besar untuk pembelian pulsa dan koneksi internet. ${ }^{16}$

Hasil penelitian ini memperlihatkan bahwa orang tua yang memiliki stresor pekerjaan atau masalah pekerjaan ialah sebanyak 63 responden $(59,4 \%)$ dengaan tingkat kecemasan berat 23 orang $(29,5 \%)$, kecemasan sedang 19 orang $(30,2 \%)$, dan kecemasan ringan 5 orang $(7,9 \%)$. Hasil uji 
chi square menunjukkan bahwa nilai stresor pekerjaan $\mathrm{x}^{2}$ hitung $=8,427$ dengan $\mathrm{p}=$ 0,038 . Nilai $\mathrm{x}^{2}$ tabel $=7,814$ pada derajat $(\mathrm{dk})=3$ sehingga dapat diinterpretasikan bahwa terdapat hubungan bermakna antara stresor pekerjaan dengan tingkat kecemasan orang tua karena nilai $\mathrm{x}^{2}$ hitung $>\mathrm{x}^{2}$ tabel dan $\mathrm{p}<0,05$. Pada hasil analisis regresi linear berganda, stresor pekerjaan memiliki nilai t hitung sebesar $-1,074$. Nilai ini lebih kecil dari pada t tabel yaitu 1,983 dan $\mathrm{p}$ $>0,05$. Hal ini menjelaskan bahwa stresor pekerjaan berperan terhadap tingkat kecemasan orang tua di masa pandemi COVID19. Berdasarkan hasil penelitian, sebanyak $63(58,9 \%)$ responden memiliki masalah pekerjaan. Hal ini disebabkan karena di masa pandemi COVID-19 ini banyak yang terkena pemutusan hubungan kerja (PHK), potongan gaji, dan tekanan dari atasan.

Pada penelitian ini didapatkan bahwa orang tua yang memiliki waktu mendampingi sebanyak 91 responden $(84,4 \%)$ dengan tingkat kecemasan berat 31 orang $(34,1 \%)$, tidak mengalami kecemasan 28 orang $(30,8 \%)$, kecemasan sedang 21 orang $(23,1 \%)$, dan kecemasan ringan 11 orang $(12,1 \%)$. Hasil uji chi square menunjukkan bahwa nilai waktu mendampingi $\mathrm{x}^{2}$ hitung $=1,260$ dengan $p=0,739$. Nilai $x^{2}$ tabel $=7,814$ pada derajat $(\mathrm{dk})=3$ dapat diinterpretasikan tidak terdapat hubungan antara waktu mendampingi dengan tingkat kecemasan orang tua karena nilai $\mathrm{x}^{2}$ hitung $<\mathrm{x}^{2}$ tabel.

Pada penelitian ini didapatkan bahwa orang tua yang tidak menggunakan perangkat elektronik/gadged bersama anaknya ialah sebanyak 90 responden $(92,3 \%)$ dengan tingkat kecemasan berat 30 orang $(33,3 \%)$, kecemasan sedang 19 orang $(21,1 \%)$, dan kecemasan ringan 12 orang $(13,3 \%)$. Hasil uji chi square menunjukkan bahwa nilai penggunaan perangkat $x^{2}$ hitung $=2,764$ dengan $p=0,430$. Nilai $x^{2}$ tabel $=7,814$ pada derajat $(\mathrm{dk})=3$ sehingga dapat diinterpretasikan bahwa tidak terdapat hubungan antara penggunaan perangkat dengan tingkat kecemasan orang tua karena nilai $\mathrm{x}^{2}$ hitung $<\mathrm{x}^{2}$ tabel.

Pada penelitian ini didapatkan bahwa orang tua yang memahami penggunaan perangkat elektronik/gadged sebanyak 101 responden $(94,4 \%)$ dengan tingkat kecemasan terdiri dari 35 orang $(34,7 \%)$ tidak mengalami kecemasan, 33 orang $(32,7 \%)$ mengalami kecemasan berat, 22 orang $(21,8 \%)$ mengalami kecemasan sedang, dan 11 orang $(10,9 \%)$ mengalami kecemasan ringan. Hasil uji chi square menunjukkan bahwa nilai pemahaman penggunaan perangkat $\mathrm{x}^{2}$ hitung $=3,276$ dengan $p=0,351$. Nilai $x^{2}$ tabel $=0,814$ pada derajat $(\mathrm{dk})=3$ sehingga dapat diinterpretasikan bahwa tidak terdapat hubungan antara pemahaman penggunaan perangkat dengan tingkat kecemasan orang tua karena nilai $x^{2}$ hitung $<x^{2}$ tabel. Pada masa pandemi COVID-19 orang tua dituntun untuk mengerti dan memahami teknologi. Hal ini dibutuhkan untuk menunjang proses pembelajaran di rumah. ${ }^{16}$

Pada penelitian ini didapatkan bahwa orang tua yang biasa mendampingi anaknya sebanyak 84 orang $(78,5 \%)$ terdiri dari 30 orang $(35,7 \%)$ tidak mengalami kecemasan, 29 orang $(34,5 \%)$ mengalami kecemasan berat, 14 orang $(16,7 \%)$ mengalami kecemasan sedang, dan 11 orang $(13,3 \%)$ mengalami kecemasan ringan. Hasil uji chi square menunjukkan bahwa nilai stresor ekonomi $\mathrm{x}^{2}$ hitung $=5,012$ dengan $p=0,171$. Nilai $x^{2}$ tabel $=7,814$ pada derajat $(\mathrm{dk})=3$ sehingga dapat diinterpretasikan tidak terdapat hubungan antara kebiasaan mendampingi dengan tingkat kecemasan orang tua karena nilai $\mathrm{x}^{2}$ hitung $>\mathrm{x}^{2}$ tabel. Pada hasil analisis regresi linear berganda, kebiasaan mendampingi anak memiliki nilai $t$ hitung sebesar $-1,324$ dengan $\mathrm{p}=0,188$. Nilai ini lebih kecil dari pada t tabel yaitu 1,983 dan $\mathrm{p}>0,05$. Hal ini menjelaskan bahwa kebiasaan mendampingi tidak berperan terhadap tingkat kecemasan orang tua di masa pandemi COVID-19.

\section{SIMPULAN}

Faktor-faktor yang berperan terhadap terjadinya kecemasan orang tua anak sekolah dasar di Desa Maumbi pada masa pandemi COVID-19 ialah stresor ekonomi dan stresor pekerjaan. Kebiasaan mendampingi berhubungan tetapi tidak berperan terhadap terjadinya kecemasan orang tua anak sekolah dasar di Desa Maumbi pada 
masa pandemi COVID-19.

Disarankan untuk melakukan penelitian serupa yang menggunakan metode penelitian yang lain, meningkatkan jumlah sampel, serta dapat menyertakan faktorfaktor lain yang dapat berperan terhadap tingkat kecemasan orang tua pada masa pandemi COVID-19. Bagi orang tua anak, untuk menghindari hal-hal yang dapat menimbulkan kecemasan sebaiknya melakukan kegiatan seperti membuat jadwal kegiatan rutin harian, berpikir positif, dan membatasi aliran informasi yang diterima dan mencari dari sumber terpercaya.

\section{Konflik Kepentingan}

Penulis menyatakan tidak terdapat konflik kepentingan dalam studi ini.

\section{DAFTAR PUSTAKA}

1. Kemenkes. Pedoman Pencegahan dan Pengendalian Coronavirus (COVID- 19). Vol 4. Jakarta: Kementerian Kesehatan RI, 2020. doi:10.33654/math.v4i0.299

2. World Health Organization (WHO). Pneumonia of unknown cause - China. Available from: https://www.who.int/ csr/don/05-january-2020-pneumoniaof-unkown-cause-china/en/

3. Zhu N, Zhang D, Wang W, Li X, Yang B, Song $\mathrm{J}$ et al. A novel coronavirus from patients with pneumonia in China, 2019. N Engl J Med 2020; 382:727-33. Doi:10.1056/NEJMoa2001017

4. Lu R, Zhao X, Li J, Niu P, Yang B, Wu H, et al. Genomic characterisation and epidemiology of 2019 novel coronavirus: implications for virus origins and receptor binding. Lancet. 2020;395(10224): 565-74.

5. WHO. Statement on The Second Meeting of the International Health Regulations (2005) Emergency Committee Regarding The Outbreak of Novel Coronavirus (2019nCoV). Available from: https://www. who.int/news-room/detail/30-01-2020statement-on-the-second-meeting-ofthe-international-health-regulations(2005)-emergency-committeeregarding-the-outbreak-of-novelcoronavirus-(2019-ncov)
6. WHO Coronavirus Disease (COVID-19) Dashboard | WHO Coronavirus Disease (COVID-19) Dashboard. [cited Nov 13, 2020. Available from: https://covid19. who.int/

7. Peta Sebaran | Satgas Penanganan COVID-19. [cited Nov 13 2020]. Available from: https://covid19.go.id/peta-sebaran

8. Passos L, Prazeres F, Teixeira A, Martins C. Impact on mental health due to covid-19 pandemic: cross-sectional study in Portugal and Brazil. Int J Environ Res Public Heath. 2020;17(18):6794.

9. Apriyanti C. The parents role in guiding distance learning and the obstacle during covid-19 outbreak. J Ilm Pendidik Dasar. 2020;VII(2):68-83.

10. Taylor BC, Arnow B. The Nature and Treatment of Anxiety Disorders. e-book International Psychotherapy Institute, 2017. Available from: https:// academyalef.com/wp-content/uploads/ 2021/01/the_nature_and_treatment_of_ anxiety_disorders1.pdf. Doi:10.1176/ ajp.147.1.117-a

11. Stern T, Fava M, Wilens T, Rosenbaum J. Massachusetts General Hospital Comprehensive Clinical Psychiatry (2nd ed). Massachusetts: Eslevier, 2016.

12. Sadock BJ, Sadock VA, Ruiz P. Kaplan \& Sadoc's Synopsis of Psychiatry (11th ed). Wolters Kluwer, 2014.

13. Cameron EE, Joyce KM, Delaquis CP, Reynolds K, Protudjer JLP, Roos LE. Maternal psychological distress \& mental health service use during the covid19 pandemic. J Affect Disord. 2020; 276:765-74.

Doi:10.1016/j.jad.2020.07.081

14. Megatsari H, Laksono AD, Ibad M, Herwanto YT, Sarweni PK, Geno RAP, et al. The community psychosocial burden during the covid-19 pandemic in Indonesia. Heliyon. 2020;6(10):e05136. Doi:10.1016/j.heliyon.2020.e05136

15. Rusman ADP, Umar F, Majid M. Kecemasan masyarakat selama masa pandemi covid19. J Kesmas Khatulistiwa. 2021; (1):1018. Doi:10.29406/jkmk.v8i1.2554

16. Cahyati N, Kusumah R. Peran orang tua dalam menerapkan pembelajaran di rumah saat pandemi covid 19. J Golden Age. 2020; 4(01):4-6. Doi:10.29408/jga.v4i01.2203 